\title{
Preliminary Version of Psychological Problems Scale- Teacher Form: Development and Psychometric Evaluation
}

\author{
Saeed Akbari Zardkhaneh ${ }^{* 1}$, Ali-Mohammad Zanganeh ${ }^{2}$, Nader Mansour Kiaee ${ }^{3}$, Mojtaba Mahdavi ${ }^{4}$, \\ Maryam Alebuieh $^{5}$, Mohsen Jallalat-e-Danesh ${ }^{6}$, Einollah Taymouri ${ }^{7}$, Siyamak Tahmasebi Garmtani ${ }^{8}$ \\ 1. Assisstant Professor, Department of Applied Psychology, Faculty of Psychology and Education, University of Shahid Beheshti, \\ Tehran, Iran \\ 2. Ph.D. in Management, Preventive Department of Judicial System, Tehran, Iran \\ 3. Ph.D. in Social Communications Sciences, Faculty of Social Sciences, Allameh Tabataba'i University, Tehran, Iran \\ 4. Ph.D. Student of Psychology and Education of Exceptional Children, Faculty of Psychology and Education of Exceptional \\ Children, University of Tehran, Tehran, Iran \\ 5. M.A. in Clinical Psychology, Faculty of Psychology and Education, University of Tehran, Tehran, Iran \\ 6. M.A. in International Law, Preventive Department of Judicial System, Tehran, Iran \\ 7. Ph.D. Student of Educational Psychology, Faculty of Human Sciences, Qom Branch, Islamic Azad University, Qom, Iran \\ 8. Assisstant Professor, Department of Preschool Education, Faculty of Human Sciences, University of Rehabilitation and Social \\ Walfare Sciences, Tehran, Iran \\ Received: February 5, 2018 \\ Accepted: August 25, 2018
}

\begin{abstract}
Background and Purpose: Comprehensive screening for health is a major step in improving the delivery of services, so that school-based psychological services can focus on prevention, early intervention, and promotion, rather than treatment. The aim of present study was to develop a scale of mental health issues for children, based on DSM-5 model.

Method: The present study is descriptive in terms of data collection method. The statistical population of this study was composed of primary school teachers in Alborz, Kermanshah, Eastern Azerbaijan, Sistan and Baluchestan, Fars, and Khorasan Razavi. The sample included 219 teachers who were randomly selected.

Results: Item analysis showed that no items were omitted from the questionnaire. Factor analysis indicated that seven-factor structure with principal component analysis and equamax rotation which determine 40 percent of the variance, simplest and most appropriate structure for the data. In addition, all the subscale had good reliability which ranged between 0.67 (self-regulation) to 0.93 (academic achievement deficit).

Conclusion: In general, the results of this study indicate that considering the psychometric properties of the mental health scale of students in primary school, this tool can be used to study the students' behavioral and emotional problems in educational and clinical settings in Iranian population.
\end{abstract}

Keywords: Student, psychological problem, primary school, teacher, scale development

Citation: Akbari Zardkhaneh S, Zanganeh AM, Mansour Kiaee N, Mahdavi M, Alebuieh M, Jallalat-e-Danesh M, Taymouri E, Tahmasebi Garmtani S. Priliminary version of psychological problems scale- teacher form: Development and psychometric evaluation. Quarterly Journal of Child Mental Health. 2019; 6(1): 1-13.

*Corresponding author: Saeed Akbari Zardkhaneh, Assisstant Professor, Department of Applied Psychology, Faculty of Psychology and Education, University of Shahid Beheshti, Tehran, Iran. 


\section{نسخه معلم مقياس مقدماتى مشكلات روانشناختى كود كان: ساخت و ارزيابى روانسنجى}

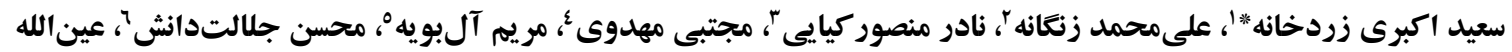

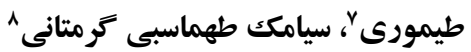

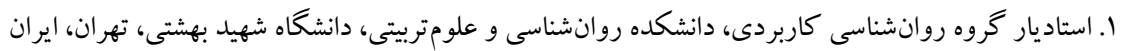

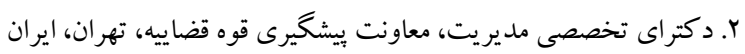

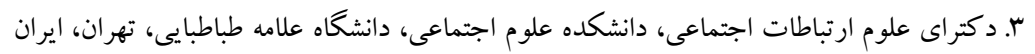

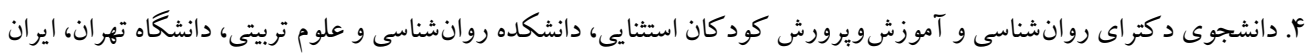

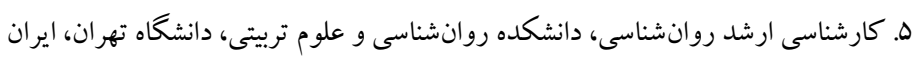

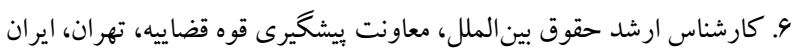

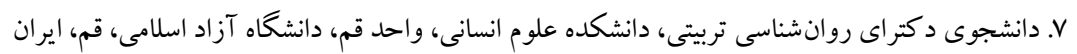

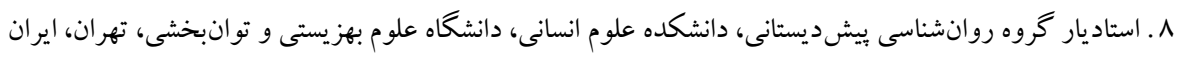

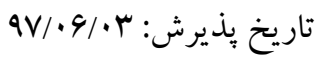

تاريخ دريافت: 99/11/199 (1)

جكيده

زمينه و هدف: غربالخرى جامع براى داشـتن سـلامت روان، گام بزرگى در بهسـازى ارائهُ خدمات اسـت، تا بدين وســيله، خدمات

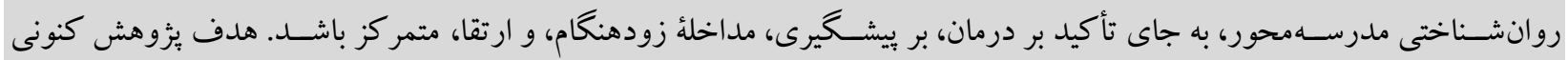

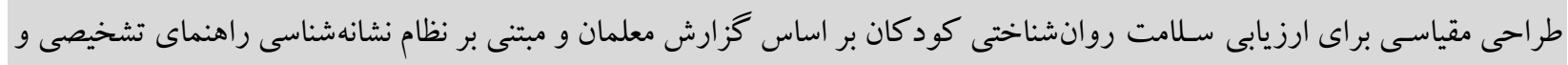
آمارى اختلالهاى روانى است. روش: يُزوهش حاضـر به لحاظ شـيوة گردآورى دادهها از نوع توصـيفى اسـت و جامعهُ آن معلمان مدارس ابتدايى اسـتانهاى البرز،

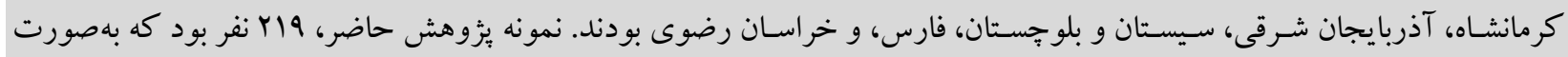
تصادفى انتخاب شدند.

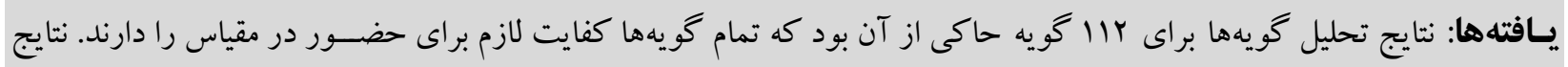

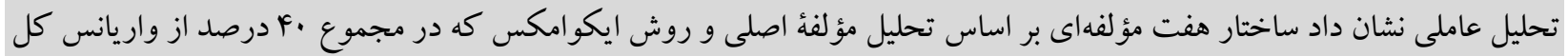

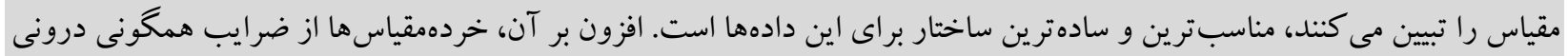

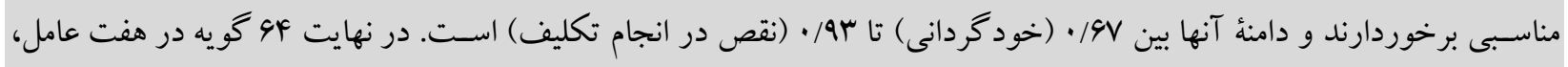
بهنوان ساختار نهايى در نظر كرفته شد.

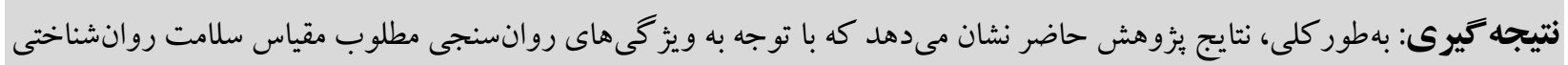

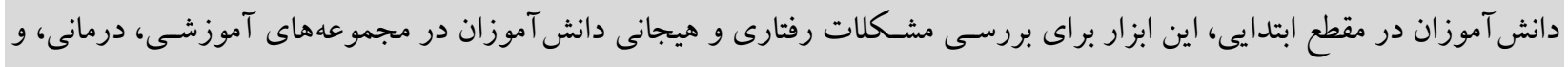
محيطهاى بالينى در جامعهُ ايرانى، قابل استفاده است. كليدوازهها: دانش آموز، مشكلات روانشناختى، مقطع ابتدايى، معلم، ابزارسازى

*نويسنده مسئول: سعيد اكبرى زردخانه، استاديار گروه روانشناسى كاربردى، دانشكده روانشناسى و علوم تربيتى، دانشكاه شهيد بهشتى، تهران، ايران. تلف:

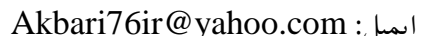


دادن آنان به سـمت تعارض و مسـئوليت گريزى و در نهايت مقدمه

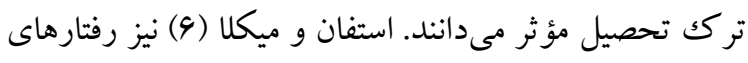

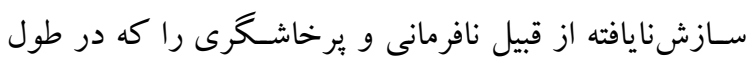

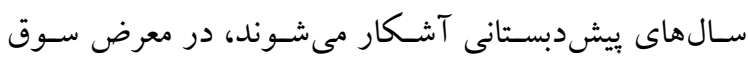

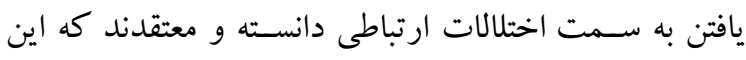
افراد رفتارهايى از قبيل بزهكارى، افت تحصيلى، سوءاستفاده

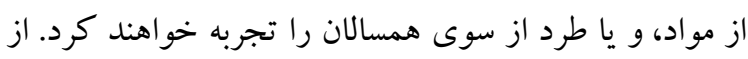

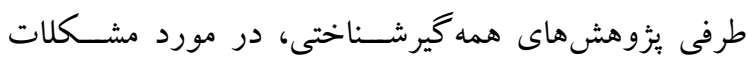

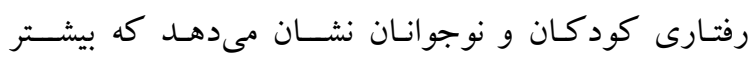

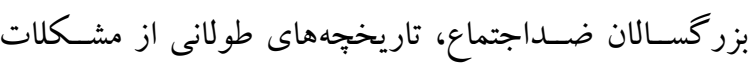
رفتـارى در دوران كودكى داشـتهاند. رفتارهاى بزهكارانه

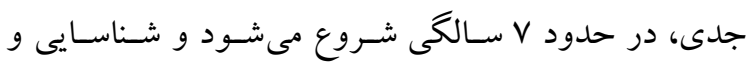

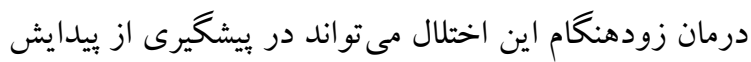
اختلالات در بزر گسالى موثر باشد (V).

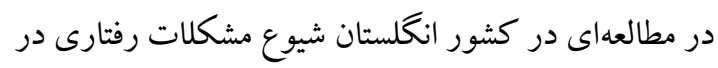
سـنين مدرسـه N/4 درصد و در سنين نوجوانى حدود 9 درصد كزارش شـده اسـت (N). در آمريكا بر اساس ملاككهاى نسخه

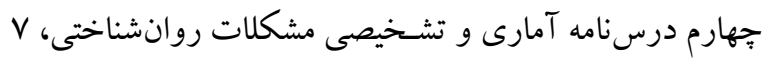

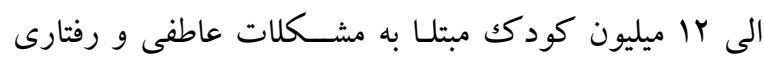

هستند (9).

يكك موضسوع مشتر كك در تمامى مطالعات ذكر شده وجود

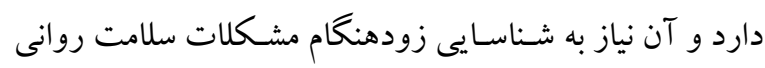

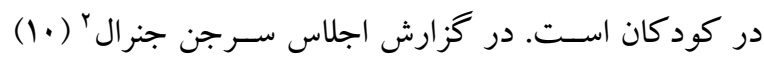

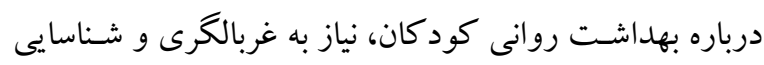
زودهنگام كود كان در درون سـيسـتمهاى خدمات كليدى، رونه

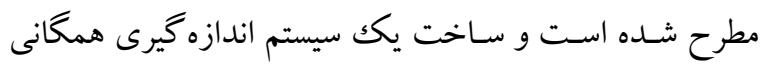
براى كليه بخشهاى خدماترسـانى اصلى، الزامى دانسته شده

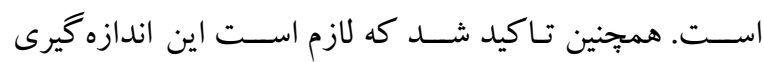

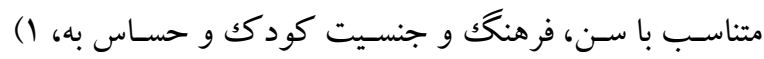

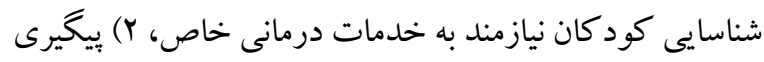

بديهى اســت در هر جـامعهاى ســلامت روان كودكان و نوجوانان از اهميت ويثهاى برخوردار بوده اسـت و و تأمين

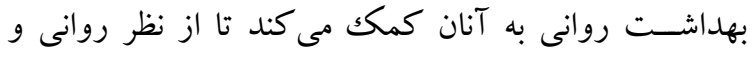
جسمانى سـالم و نقش اجتماعى خود را بهتر ايفا كنند. وجود اختلالات رفتارى و هيجانى در دوره كودكى مسـئله مهمى

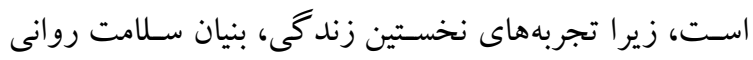

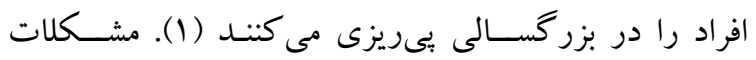

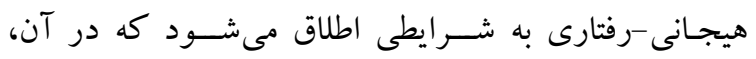
ياسخهاى هيجانى و رفتارى در مدرسه با هنجارهاى فرهنگى،

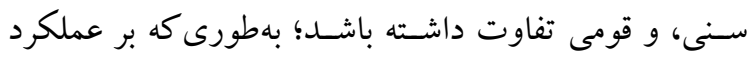

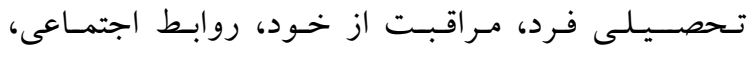
سـازش يافتكى فردى، رفتار در كلاس، و سـازشيافتخى درد محيط كار نيز تأثير منفى بخذارد (Y).

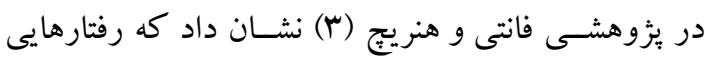

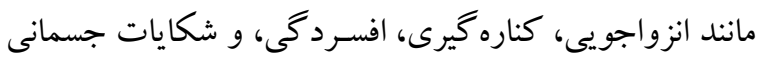

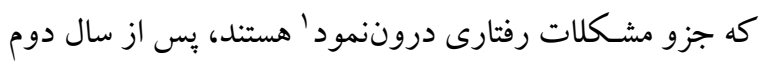

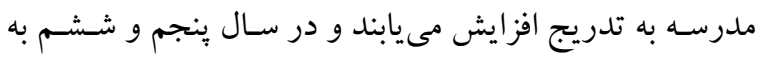

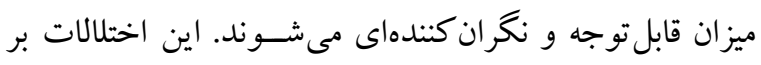
اساس دادهاى حاصل از منابع مختلف در مورد كار كردهاى هيجانى يا رفتارى فرد، شناسايى مى شوند و بايد دست كم در دو موقعيت متفاوت كه يكى از آنها مدرسـه است بروز كنئد. اغلب كود كان و نوجوانان با اختلالات رفتارى، احسـاسـات منفى دارند و با ديخران بدرفتارى مى كنتد. در بيشـتر موارد معلمان و همكلاسـىها، آنان را طرد مى كنند و در نتيجه فرصـتهاى آموزشى آنان كاهش مى يابد؛ در واقع، اختلالات رفتارى هيجانى مىتواند مشـكلات تحصـيلى متعددى براى دانش آموزان ايجاد كند (F).

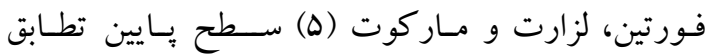
دانش آموزان داراى مشـكل رفتارى، فقدان احترام به قوانين،

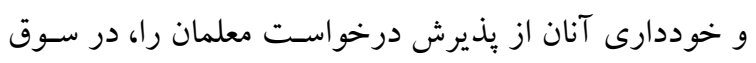


فرايند غربال گرى شـامل سـه مرحله اســت. در مرحله اول از

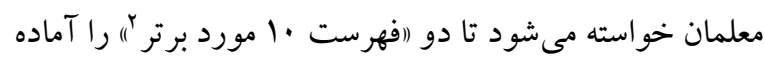

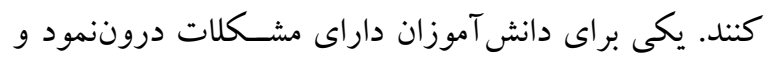

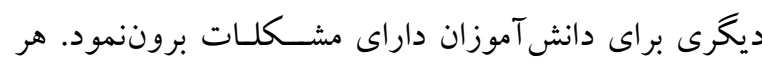

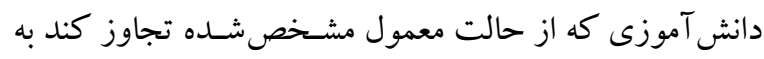
مرحله بعدى مىرود. در مرحله بعد دانش آموزانى كه در بايان

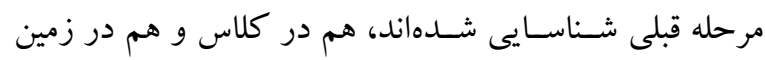

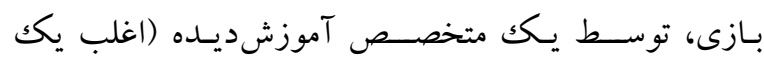
متخصسص رفتارى يا روانشـناس مدرسـه) مورد مشـاهده قرار

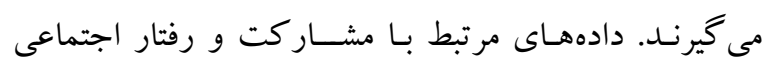
بهمنظور تبيين نتايج مقايسهاى، رتبهبندى شده و بر اى كمكك به تصــميم گيرى در رابطه با مداخله يا ارجاع، ثبت مى شـــوند.

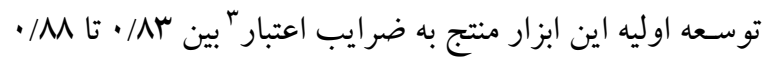

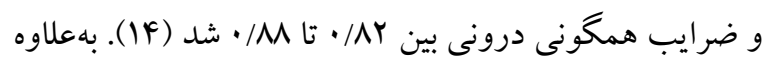

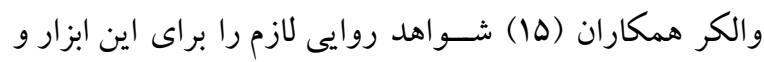

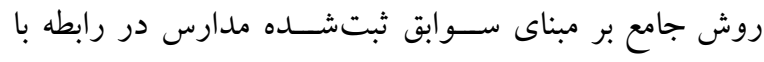
طبقهبندىهاى رفتار و تحصيلات استثنايى، ارائه كردهاند؛ با اين حال اجراى اين ابزار به مدتزمان طولانى در سه مرحله نيازمند است. يـكى ديـحـر از مـقيـاسهـاى رايـج بـراى غربـالخرى

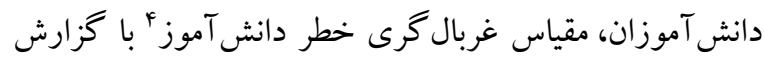
معلم اسـت كه بهمنظور شــاسـايى خطر مشـكلات رفتارى كود كان در سـن مهدكود كك تا كلاس شـشــم، طر احى شـده اسـت. در رابطه با شـواهد اعتبار، لين و همكاران (19) مقياس

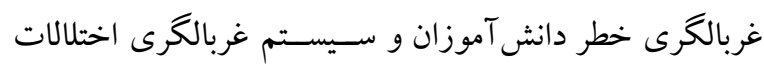
رفتارى را از مهدكودك تا كلاس سـوم با يكديخر مقايسـهـ

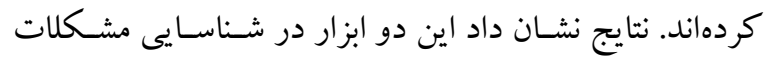

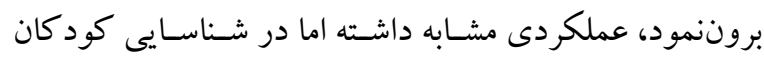

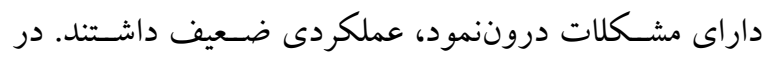
مطالعات جديدتر براى بالابردن توان مقياس غربال گرى خطر مُردئ

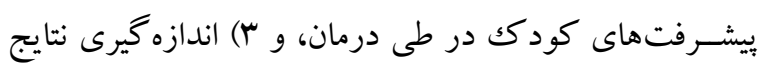
درمانى باشد.

هسـتر و همكاران (11) به اين نتيجه رسـيدهاند كه به نظر مىرســـ شـناسـايى و مداخله زودهنگكام در دانش آموزان در معرض خطر اختلالات رفتارى و عاطفى، قدرتمندترين اقدام در جهت بهبود مشكلات مرتبط با كود كان در معرض خطر در تمام طول عمرشان باشد. همجينين نتايج يزوهش ها نشان دادهاند شـناسـايى و درمان زودهنگام كود كان، قبل از بروز مشـكلات عاطفى و رفتارى آنها مىتواند عوارض طولانىمدت اختلالات روانى مثل كاهش كلى هزينههاى درمانى و به حداقل رسسيدن آسـيبـهاى بلندمدت را به همراه داشـته باشـد. كود كى زمانى حياتى براى شـناسـايى و جلو گيرى از اختلالات روانى مزمن و همجنين ترويج رشد سالم است. براى انجام اين مهم، كود كان در معرض خطر بايد به دقت شـناسايىشده و به سرعت به آنها خدمات لازم ارائه شود (Y) (I). غربالخرى مشـكلات روانى توسـط سـازمانهاى تخصصى همجيون انجمن روانشناسى كود كان آمريكا اكيداً توصيه شده اسـت و هزينهُ آن توسـط سـازمان كمككهاى يزشـكى تأمين مىشود (سا). غربال گرى سلامت روانى در گستره مدرسه، گام اوليه ضــرورى براى يكك فرايند تصـميم گيرى داده- محور بهمنظور شناسايى كود كان در معرض خطر و ارزيابى رفتارى و عـاطفى آنها اســت؛ به كونهاى كه از طريق كاهش خطر و جلو گيرى از بروز اختلالات تشــخيصـى، نتايج را به شـكل قابل ملاحظهاى بهبود مىبخشـد. اين موضـوع بهويزه در بافت مدارس كه در آنها كود كان بهعنوان يكك جمعيت در دسترس هستند، صدق مى كند (If). در اين راسـتا غربال گرى نظامند اختلالات رفتارى' روندى جندمر حلهاى اسـت كه بهمنظور شناسايى آن دسته از كود كان مدارس ابتدايى توسـعه داده شــده اسـت كه در معرض خطر شـديد مشـكلات رفتارى دروننمود و برونتمود هسـتند. اين

1. Systematic screening for behavior disorders (SSBD) 2. Top 10 Listings 
همبوشـانى اختلالات در حيطه روانشــاسى مرضى كودكى در شــناسـايى كودكان با اختلالات كلىتر، بهتر عمل مى كرد.

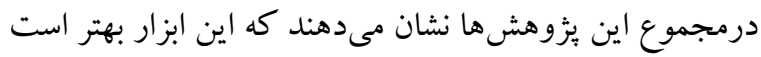
كه بهعنوان يك شـاخص سـازش نايافتكى عمومى به كار رود.

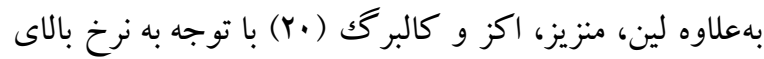
مـنفى كـاذبه اين آزمون، كـاربرد آن را در برنسامسهـهاى

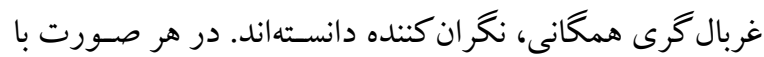
توجه به نو اقص ابزارهاى ياد شـده، يكى از مشكلات اساسى بر هرب

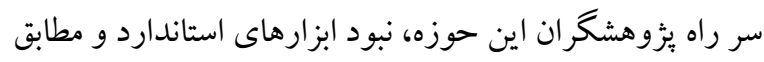

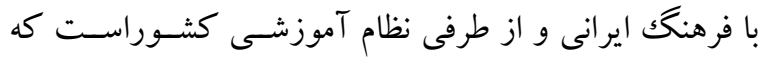
كاهى اوقات نتايج يثوهش ها را تحت تأثير خود قرار مىدهد.

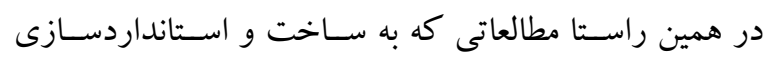
ابزارهاى مناسب با نظام و فرهنگك آموزشى جو امع مى يردازند،

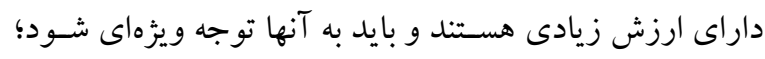
بنابر اين بزوهش حاضسر در نظر دارد تا ضسمن طر احى مقياسى

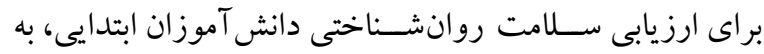
بررسى ويز گیى هاى روانسنجى آن بيردازد.

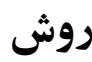

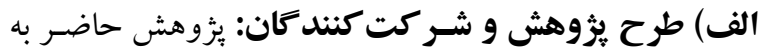
لحاظ هدف، جزء بثوهشهاى تحقيق و توسـعه و به لحاظ

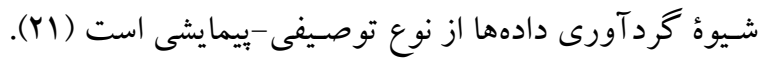
جامعه آمارى در اين يُووهش، معلمان دانش آموزان مدارس

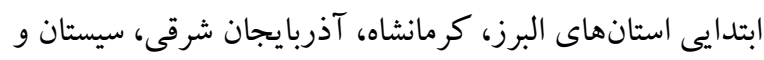
بلوجسـتان، فارس، و خراسـان رضوى در سـال تحصيلى 99-

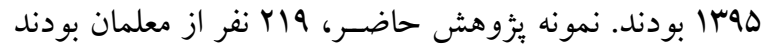
كه از جهار اسـتان كرمانشـاه، تبريز، فارس و خراسـان و در

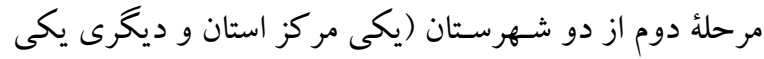

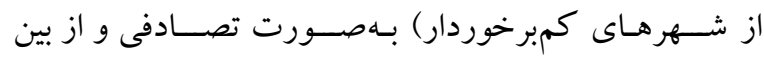

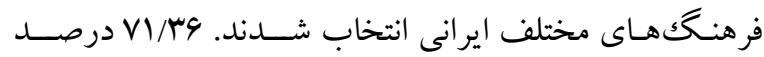

3. Sensitivity

4. Specificity

5. False negative
دانش آموز در شـناسايى مشكلات دروننمود، گويههايى از آن را تغيير دادهانــ. با وجود اين تغييرات، مطالعات اوليه تحليل عاملى، نتايج اميدوار كنندهاى ايجاد نكرده است (|f) )، بنابراين اين ابزار از توان لازم براى سنجش همزمان مشكلات را ندارد.

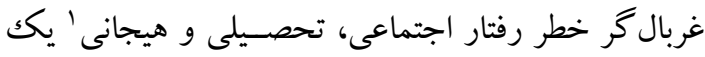

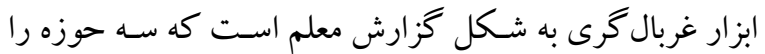
دربرمى گيرد: رفتار اجتماعى، رفتار تحصسيلى، و رفتار عاطفى.

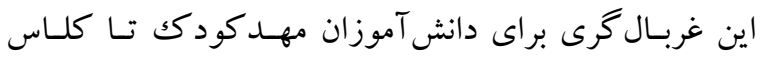

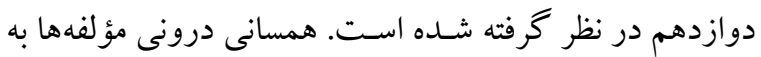

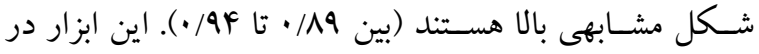
ســنش رفتارهاى هيجانى، جِندان توفيقى نداشـته اسـت و و همجنين درباره شو اهد روايى ويشيينى آن مطالعات زيادى در دسترس نيست. زمانى كه جند معلم مختلف رتبهبندى مشابهى

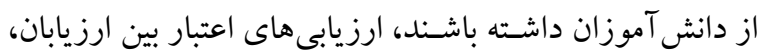

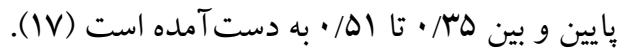

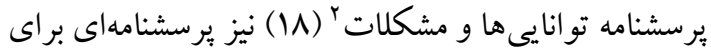

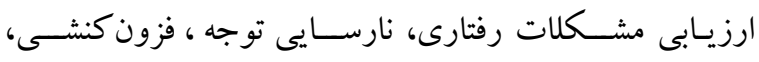

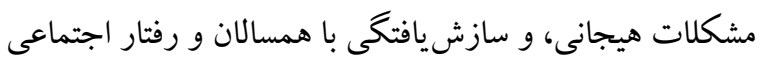

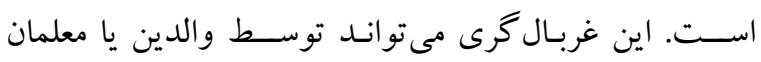

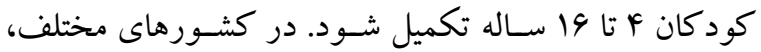
مشاهده شده است كه اعتبار همسانى درونى آن V9/• و اعتبار آزمون-باز آزمون 99/•، بهدسـت آمده اسـت، اما همســانى درونى معيـارهـاى انفرادى، بـه جزء معيـار نارســايى توجه-

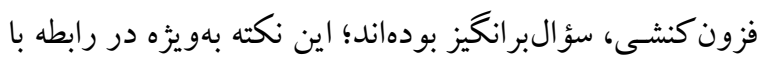

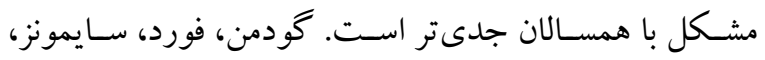

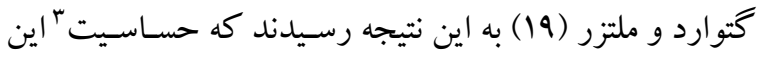

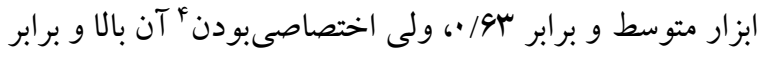

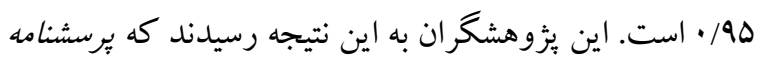
توانايىها و مشكلات با وجود اين كه براى شناسايى اختلالات خاص طراحى شـــده بود، به دليل اختلالهاى همزمان و نيز

1. Social Academic Emotional Behavioral Risk Scale (SAEBRS)

2 .The strengths and difficulties questionnaire(SDQ) 
در معرض سـوءاسـتفادهُ جنسـى و جسـمى بهعنوان اولويت غربال گرى انتخاب شد.

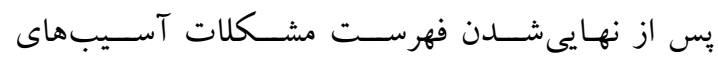
روانشناختى شايع در بين دانش آموزان، در اين مرحله اقدام به

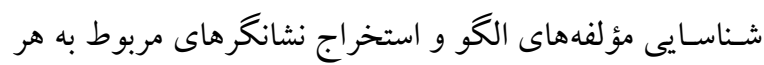

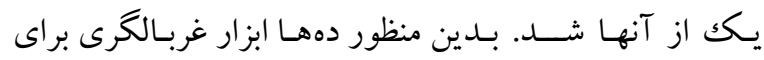

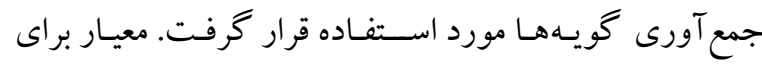

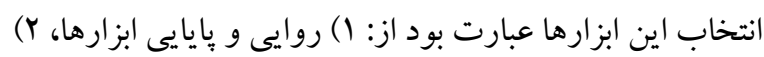

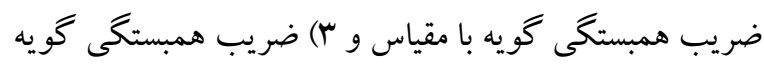

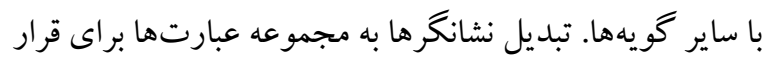
دادن در ابزار، منجر به تهيه بانكك سـؤالها شــــ براى مقياس

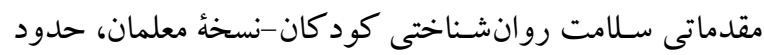

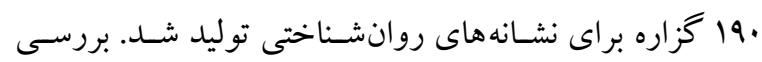

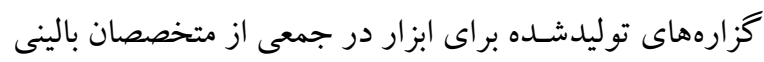
حوزه آسـيبهاى روانشـناختى دوران كودكى و نوجوانى،

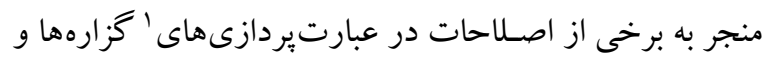

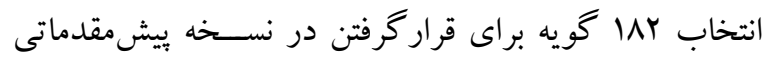
يكم مقياس شد.

بررسـى روايى صـورى طى جلسـات گروهى با معلمان

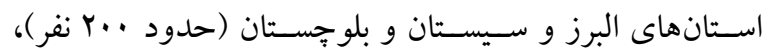

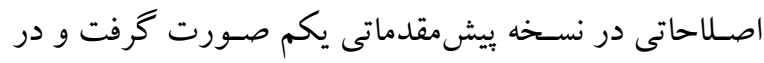

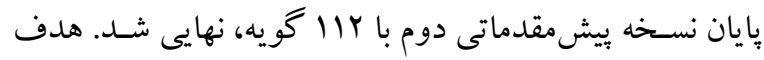

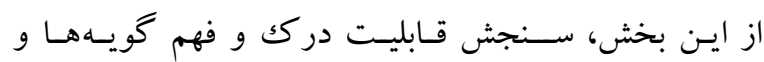

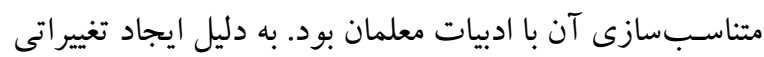
در نسـخه اوليه ابزار، جهت حصـول اطمينان از حضور ساختار نظرى و بالينى در ابزار و سـنجش روايى محتوايى ابزار، از ده

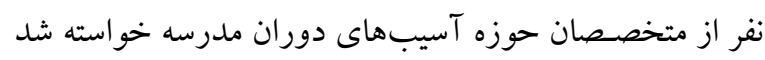
بررسـهاى لازم را در خصـوص روايى محتوايى ابزار انجام دهند. نتيجه اين كام نيز نشان از وجود همخر ايى در نظر داوران

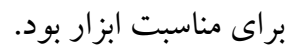

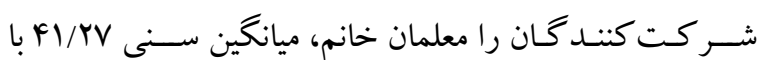

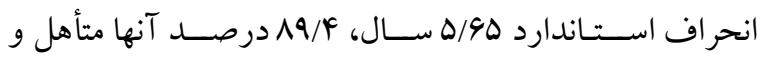

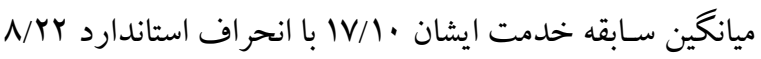
بود. اين حجم از نمونـه براى انجام تحليل عاملى اكتشــافى از

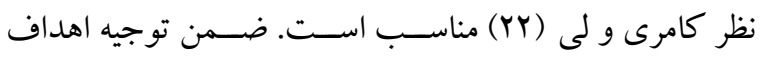
تحقيق، برسـشـنامهها در اختيار معلمان قرار داده شـــ و از آنها خواسته شد تا با توجه به اطلاعاتى كه در دانش آموزان مربوطه ئه در دست دارند، برسشنامهها را تكميل كنند.

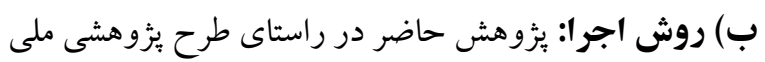

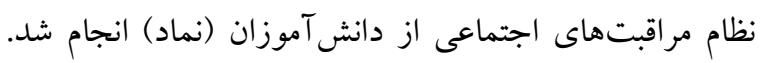
فرايند اجرايى اين طرح در قالب ائتلافى با مشاركت دانشگاه شهيد بهشتى، دانشگاه علوم بهزيستى و توانبخشى، قوه قضاييه، نيروى انتظامى جمهورى اسلامى ايران، رياست جمهورى اسلامى ايران، وزارت تعاون، كار و رفاه اجتماعى جمهورى

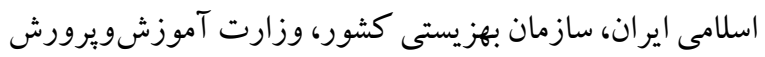
جمهورى اسلامى ايران، كميته امداد امام خمينى، وزارت بهداشت، درمان و آموزش يزشكى جمهورى اسلامى ايران، و و

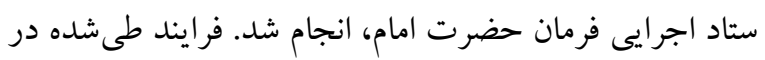
اين يثزوهش از مراحل زير كذشته است:

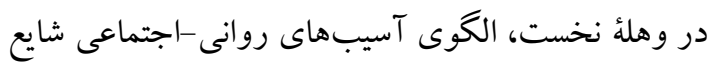
دانش آموزان كشـور استخراج شد. بدين طريق كه ابتدا يبشينه يثزوهشـى حوزه آسـيبـهاى دوران كودكى و مسـتـندات

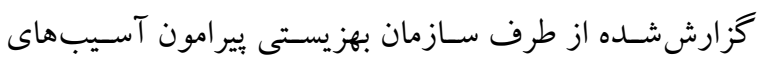

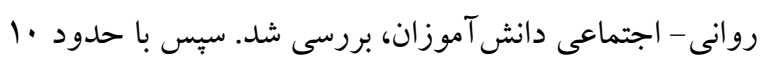

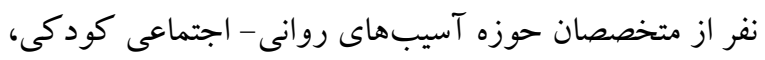
مصاحبه فردى شد و از آنها خواسته شد تا شايع ترين مشكلات

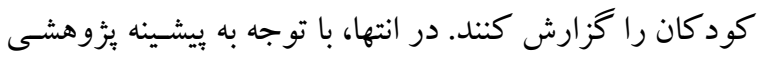
حاضـر و نظر متخصصان، هشت آسيب روانشناختى نارسايى

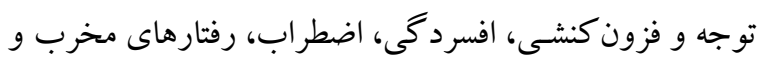

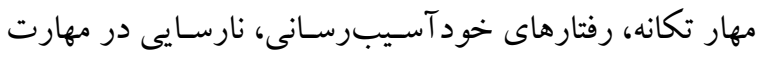
انجام تكاليف تحصسيلى، نارسـايى در خودگر دانى، و كود كان

1. Wording 
نبود دادههاى برت، نبود همخطى بودن در دادهها و عامل يذيرى

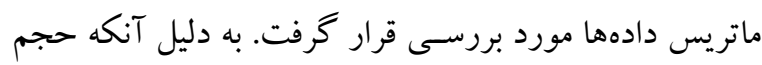
نمونه براى تحليل عاملى در حد عالى بود، بنابر اين نياز جندانى ترنى

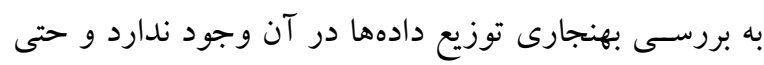
عـدم بهنجـارى توزيع برخى از دادههـا در نتايج خللى وارد

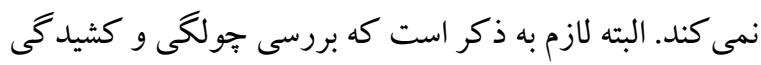
بهعنوان ملاكى براى انتخاب كويهها موجبات بهبود شــــايط

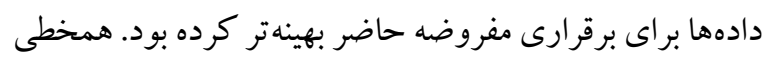

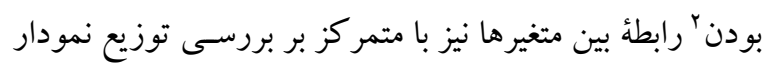

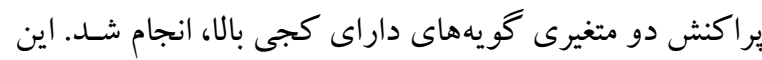

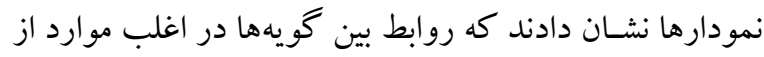
نوع خطى و در موارد اندكى نزديكك به خطى اسـت، لذا به دونه

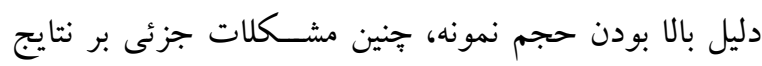

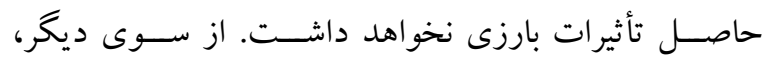

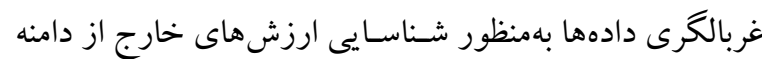

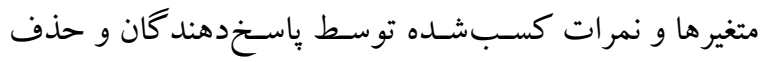

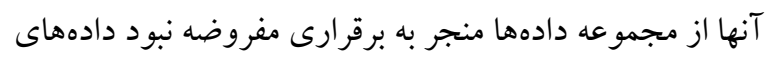

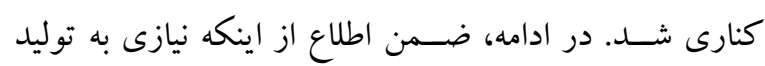
ماتريس معكوس \ در تحليل مؤلفهها وجود ندارد و در نتيجه همخطى جّند كانه مشـكل اسـاسـى براى انجام آن به شـمار

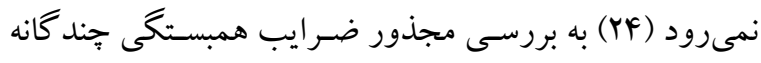

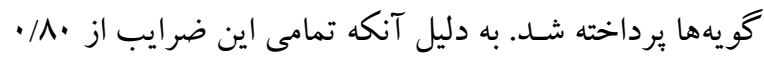

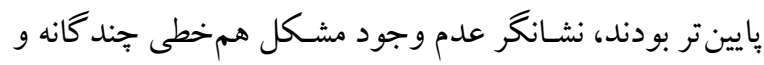

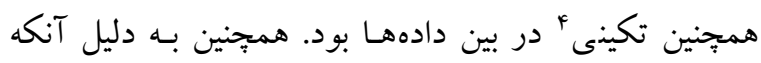
مقدار شـاخص كفايت نمونهبردارى كيسر -ماير -الكين ه (Yه) بهدسـت آمده برابر با هی/· و شـاخص آزمون كرويت بارتلت

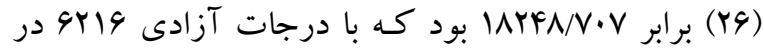

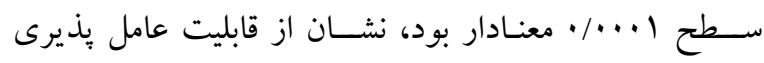
مـاتريس مربوطه داشـت (YF)؛ بنابراين در مجموع برقرارى

4. Fitness

5. Kaiser-Mayer-Olkin (KMO)
پِّ از اطمينـان از روايى صــورى و محتو ايى نســــهـ

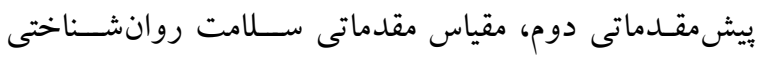

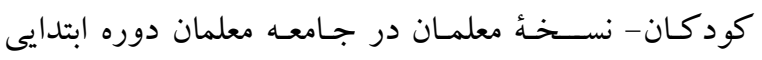
اسـتانهاى كرمانشــاه، آذربايجان شــرقى، فارس و خراســان

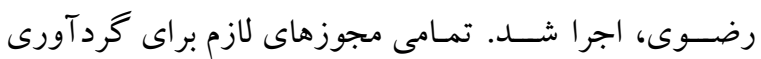

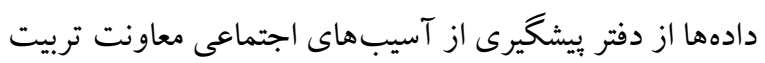

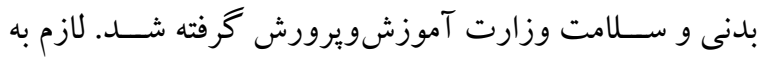
ذكر است كه در تمامى مر احل يثزوهش به شركت كنند كان در يُزوهش اين اطمينان داده شد كه اطلاعات دريافتشده محرمانه باقى خواهد ماند و دادهها بهصسورت كلى تحليل خواهد شــد.

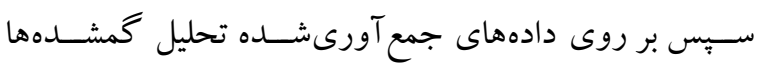
صـورت گرفـت و گويـهــاى مورد تحليل قرار گرفتند و در

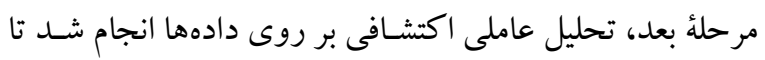
روايى سازه نيز مورد ارزيابى قرار گيرد.

\section{يافتهها}

تحليل گويهها بر روى هر كدام از هفت خردهمقياس انجام شد. در طى فرايند تحليل گويهها بررسى نمودار ستونى درصدى، مري،

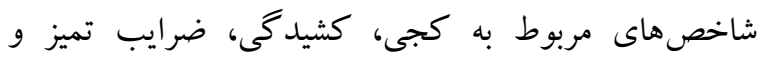

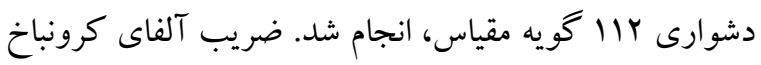
كل مقياس در شرايط حاضر، 9 / • به دست آمد. تحليل بر روى هر گويه، مستلزم محاسبة سهم شر كت كنند گانى كه به هر گزينه

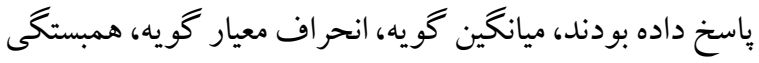

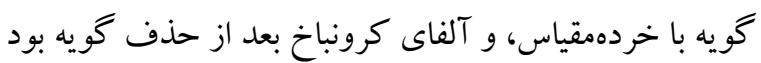

تحليل عاملى اكتشـافى فرم معلمان براى شـناسايى و تفسير تعداد عوامل نهفته اجرا شد. تعداد عوامل اوليه كه توسط قانون

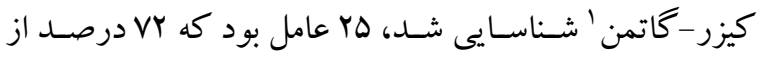
واريـانس را يوشـش مىداد. قبـل از انجـام تحليـل عـاملى، مفروضـههاى توزيع بهنجار دادهها، رابطة خطى بين متغيرها،

1. Kaiser-Gottman

2. Linearity

3. Reverse matric 
مفروضـهها انجام تحليل عاملى مشـخص و اين تحليل بر روى

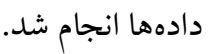

جدول ا: مؤلفهها و مجموع مجذور بار كذارى حاصل از تحليل مؤلفههاى مقياس مقدماتى كزارشى معلمان سلامتروانشناختى دانشآموزان در مقطع ابتدايى مقياس

\begin{tabular}{|c|c|c|c|c|}
\hline ارزش ويز口ه & درصدد تبيين واريانس تراكمى & درصد تبيين واريانس & ارزش ويزه & 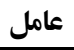 \\
\hline 1.19 & $r \Delta / \Delta F$ & $r \Delta / \Delta f$ & $r \Delta / \Delta F$ & يكم \\
\hline$V / \Delta)$ & $r 4 / 99$ & $Q / 1 r$ & $q / 1 r$ & دوم \\
\hline $\mathrm{V} / \mathrm{r} \Lambda$ & $F \cdot / A F$ & $9 / 1 \mathrm{~V}$ & $9 / 1 \mathrm{~V}$ & سوم \\
\hline$V / Y q$ & $\mu F / \mu V$ & $r / 94$ & $4 / .9$ & 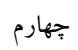 \\
\hline V/If & $49 / 19$ & r/AY & $r / M I$ & بنجنم \\
\hline$\Delta / A r$ & FANF & $1 / A F$ & $r / .4$ & 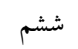 \\
\hline$\Delta / r$. & $\Delta \cdot / \Delta F$ & $1 / 19$ & $r / .1$ & هغتم \\
\hline
\end{tabular}

مثال، "اجراحاتى در بدن دارد كه دليل موجهى براى آنها وجود نــدارد)، (ادلـايـل متفـاوتى براى جراحسات موجود در بدن ارائه

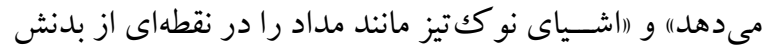
وارد مى كنـد))، نـارسـايى توجه و فزون كنشسى (براى مثال، "حرف ديخران را قطع كرده و اجـازه صسـبـت بـه آنها را نمىدهد)، (اقبل از اتمام يرسش، با عجله و بدون ملاحظه جواب

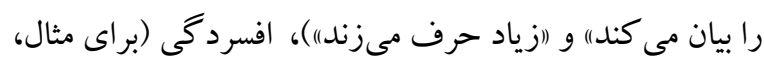

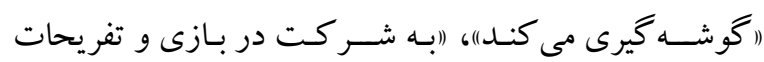

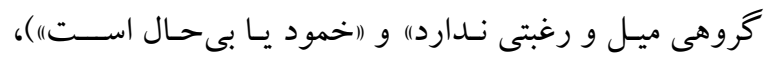

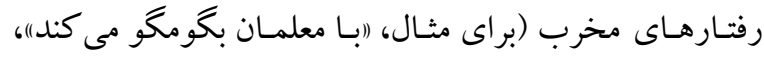
"ابر اي فرونشـاندن خشــم و عصــبانيت خود از ديخران انتقام مى گيرد) و (ازود از كوره به در مىرودد))، اضطر اب (براى مثال، "ارس شـديدى نسبت به از دست دادن يا آسيب ديدن والدين نشـان مىدهد)، ("در مواقع جدايى از مادر يا جانشين او از خود

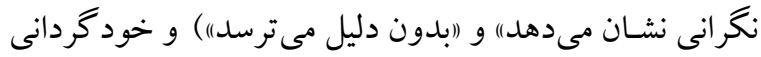

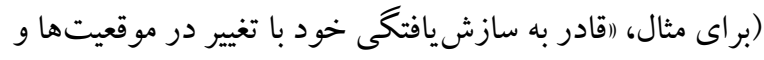

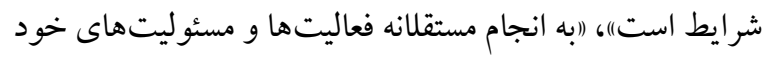
تمايل نشان مى دهد) و (امسئوليت بذير است)) نام خذارى كرد.
در تحليـل عـاملى اكتشــافى، تعـداد عوامل 9 تا م در نظر

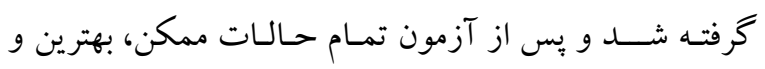
مناسـبترين ساختار بر اساس تحليل موازى تعيين شد (جدول

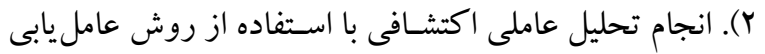

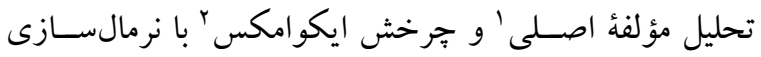
كيزر و محدود كردن تعداد عوامل به تعداد Vو حداقل مقدار بـار گذارى هر گويه روى عوامل ·ب/·، منجر به اسـتخراج عو املى شد كه داراى بيشترى همخوانى با ساختار نظرى مقياس گززارش معلمان از سلامت روانشناختى دانش آموزان در مقطع ابتدايى بودند. در پايان نتايج تحليل عاملى نشـان داد سـاختار

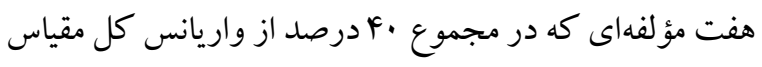
را تبيين مى كنند (جدول r)، مناسـبـترين و سـادهترين ساختار

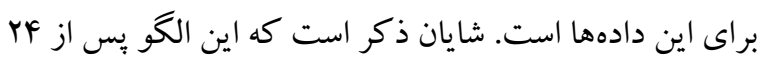
جر خش به دست آمد. تحليل عاملى اكتشـافى نشان داد مؤلفه هاى يكم تا هفتم را

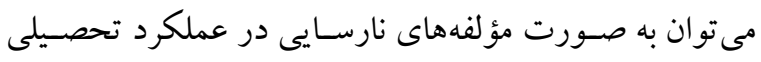
(براى مثـال، (ادر امور درســى فراموش كـار اســت)، (از انجام كامبه گام تكاليف درسىاش ناتوان است) و (اعملكرد تحصيلى إنى ضعيفى داردا))، آسيب به خود و در معرض آزارديد 
جدول با: بارهاى عاملى ناشى از تحليل عاملى اكتشافى

\begin{tabular}{|c|c|c|c|c|c|c|}
\hline عامل هفتم & عامل ششم & عامل گنجمم & عامل جهارم & عامل سوم & عامل دوم & عامل يكم \\
\hline.$/ 0$ & .199 & .191 & . /VD & $\cdot / N Y$ & $\cdot / v$ & $\cdot / V \Delta$ \\
\hline$\cdot / 4 \Delta$ & $\cdot 191$ & $\cdot / \Delta 9$ & $\cdot / v$ & $.19 \mathrm{~V}$ & .190 & .191 \\
\hline$\cdot / A r$ & .190 & $\cdot / \Delta V$ & .194 & $\cdot / \Delta \Lambda$ & .194 & $.19 \mathrm{~V}$ \\
\hline$\cdot / 4$. & .19 & $\cdot / \Delta \Delta$ & $\cdot / \Delta \mathrm{V}$ & $\cdot / \Delta \Delta$ & .194 & .194 \\
\hline • & $\cdot 109$ & $\cdot / \Delta F$ & $\cdot / \Delta \Delta$ & $\cdot / \Delta F$ & .191 & .194 \\
\hline • & - $/ \Delta r$ & $\cdot / \Delta F$ & $\cdot / \Delta r$ & •/Dr & $\cdot / 9$ & .194 \\
\hline$\cdot / \mu F$ & $\cdot / 49$ & $\cdot / \Delta F$ & $\cdot / A V$ & $\cdot / 49$ & $\cdot / \Delta 9$ & $\cdot / 90$ \\
\hline \multirow[t]{9}{*}{ r } & $\cdot / 4 \wedge$ & r/dr & $\cdot / 4 \Delta$ & $\cdot / \mu$. & $\cdot / 09$ & .194 \\
\hline & & & & & $\cdot / \Delta \mathrm{V}$ & \\
\hline & & & & & $\cdot 109$ & \\
\hline & & & & & $\cdot 109$ & \\
\hline & & & & & $\cdot 109$ & \\
\hline & & & & & $\cdot / \Delta F$ & \\
\hline & & & & &.$/ 44$ & \\
\hline & & & & &.$/ 49$ & \\
\hline & & & & & $\cdot / A F$ & \\
\hline
\end{tabular}

همجنين بررسى ضـر ايب همبســكى گويه ها با خردهمقياسها

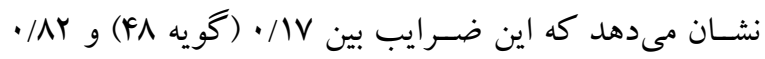

$$
\text { (كويه 19) است. (كتيه }
$$

جدول ب نيز نشــان مىدهد كه تمامى خردهمقياسها از

ضـرايب مناسـب همكونى درونى برخوردارند و دامنه آنها بين 19V • (خود گردانى) تا سو/ • (نارسايى در انجام تكليف) است.

جدول "ّ: ويزكىهاى توصيفى كويهها و خردهمقياسهاى نسخه معلمان مقياس آسيبهاى روانشناختى دانش آموزان مقطع ابتدايى

\begin{tabular}{cccccccc}
\hline & \multicolumn{7}{c}{} \\
\hline \\
\hline
\end{tabular}


مىدهـد كـه مـاتريس گويههاى قرار گرفته در مقياس داراى روابط قوى و مناسـبى هسـتند كه مى تواند منجر به اسـتخراج مولفههايى از ماتريس دادهها شــود. در ضــمن نتايج تحليل ماليل عامل هاى اكتشـافى انجامشــده نشـان داد در شـرايط استفاده از

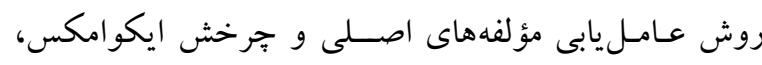
عوامل حاصـل شـده بهترين مطابقت را با مبانى نظرى نشـان

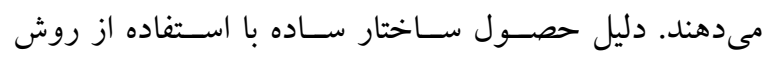

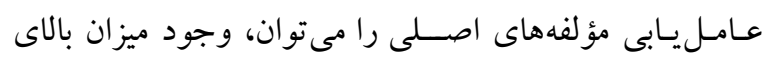

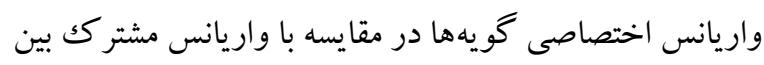

$$
\text { آنها دانست (Y9). }
$$

بلمنظور ســنش اعتبار اين مقياس نيز از ضــريب آلفاى

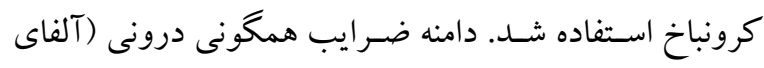
كرونباخ) مؤلفههاى اسـتخر اجى در نسـخه مقدماتى مقياس

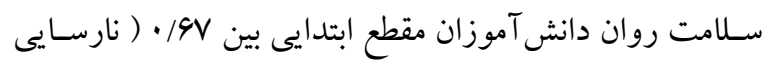
در خود گردانى) تا سوه/ ( نارسـايى در انجام تكاليف) اسـت. تمامى اين ضـرايب از نظر ميشل و جولى (·r) در حد خوب و بالاتر از آن اسـت؛ در واقع نتايج سنجش اعتبار نشان دادند كه وله

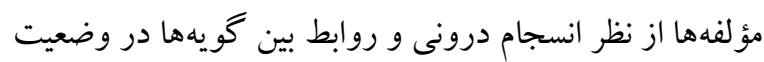
قابل قبولى قرار دارند و اين مقياس از اعتبار مناسـبى برخوردار دورد نكتهٔ ديخرى كه بايد بدان اشــاره كرد اين اسـت كه در يُزوهش حاضـر و يس از تحليل عاملى اكتشـافى، دو مؤلفهُ

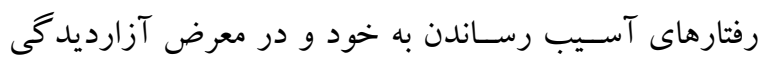
(سوءاستفاده جنسى از كود كان) با هم ادغام شدند. شايد بتوان اين نكته را بدين كونه تبيين كرد كه خردهمقياس سوء اسواستفاده

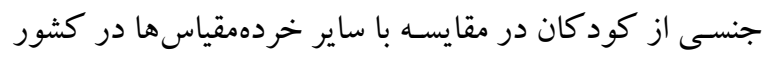

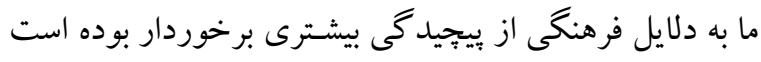

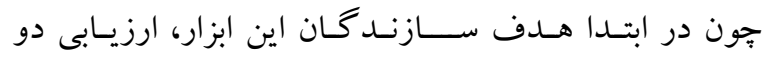
خردهمقياس جداكانه، با عنوان رفتارهاى آسـيب رسـاندن به آنه خود و وجود سـو ءاسـتفاده جنسى از كود كان بود و به همين جهت گويههايى براى آنها تهيه شــد، ولى در تحليل عاملى ونى

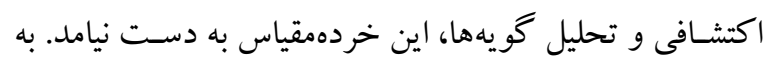

در فرم معلم، خردهمقياسهاى رفتارهاى مخرب و نارسايى

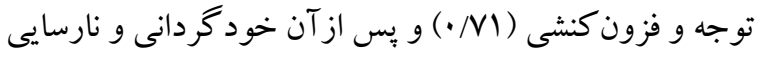

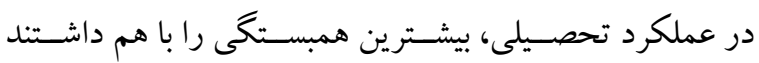

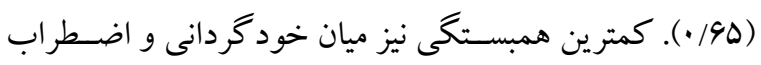
مشاهده شد (1•/•).

\section{بحث و نتيجه كيرى}

مشـكلات رفتارى كود كان، مشكلات ناتو ان كنندهاى هستند كه براى خـانو اده و كودكـان، دشـوارىهـاى بســيارى را ايجاد

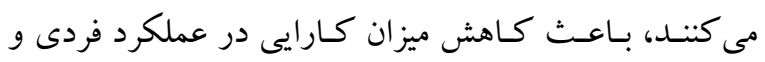

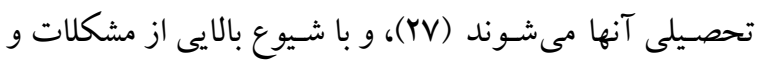
ييامدهاى اجتماعى همر اه هستيند (YN). هدف ئزوهش حاضر،

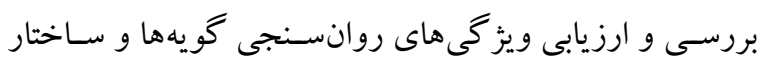

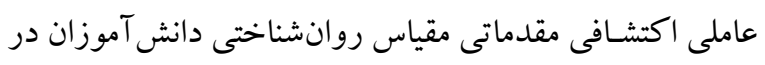

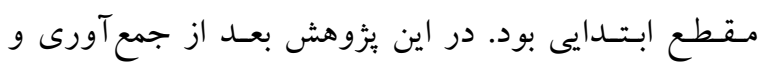

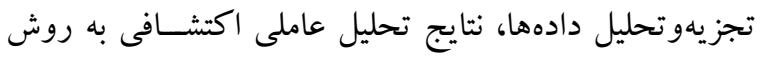

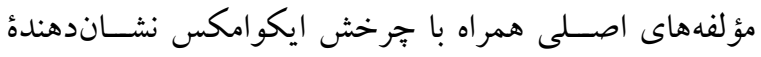

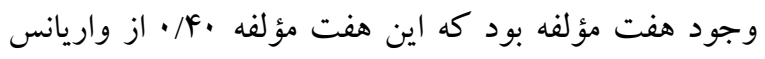

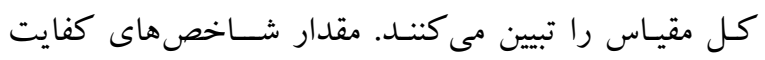
نمونهبردارى، ه内/· درصسـد اســت كه با مقدار حداقل اين

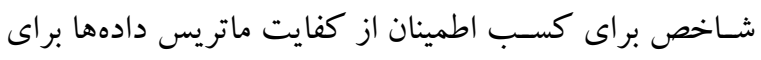

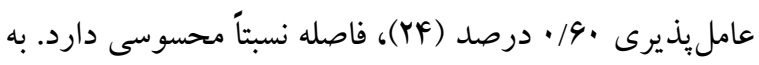
نظر كيسـر (YD) اين مقدار از شـاخص نمونهبردارى در دامنه عالى قرار دارد. اين شاخص نشان مىدهد كه مؤلفه هاى موجود در دادههاى مورد تجزيهو تحليل به ميزان مناسبى از هم قابليت

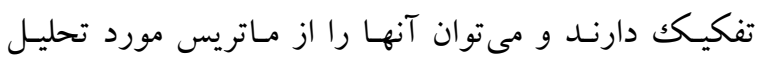

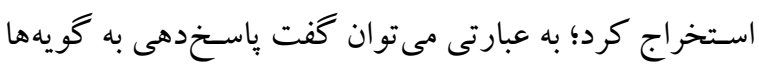
توسط افراد گروه نمونه طورى طراحىشده كه هر يكك از آنها

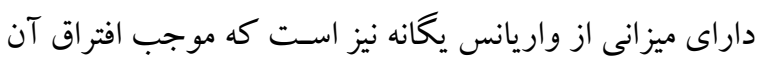

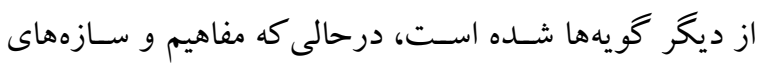
تعبيهشـده در مقياس، هم به لحاظ مفهومى و هم آمارى با هم در ارتباط هسـتند. آزمون كرويت بارتلت (Y9) هم نشهـــان 
روشهاى همزمان، واخرا، و همخرا بهمنظور بررسـى بيشـتر

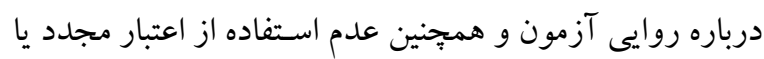

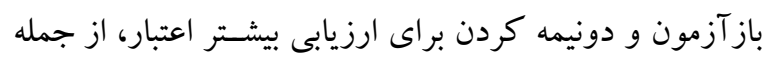

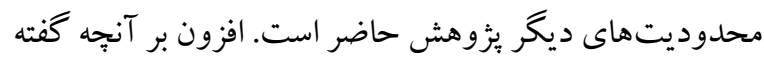

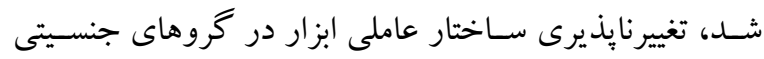
مورد بررسى قرار نخرفته است تا مشخص شود كه آيا اين ابزار

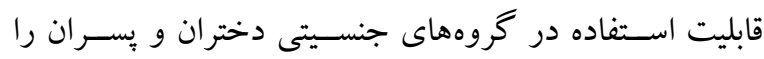

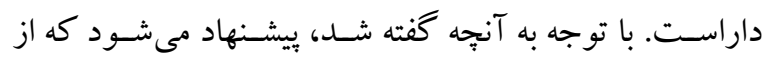

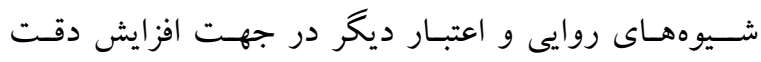
ويز گى هاى روانسـنجى مقياس حاضر استفاده شود و همجنين

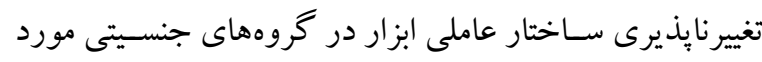
بررسى قرار گيرد. در نهايت، بيشنهاد مى شود كه از تحليل هاى برى

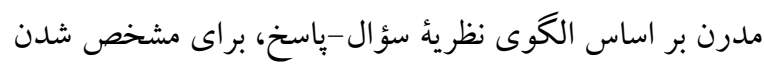

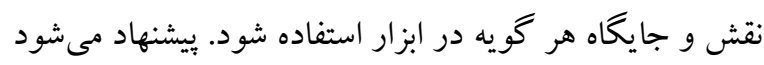
كه دادههاى غربالكرى در تصميم گيرى مبتنى بر مدل بيشخيرى

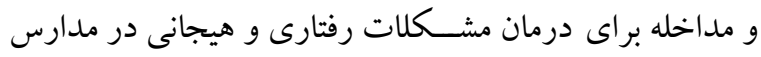
مورد استفاده قرار كيرد.

تشكر و قدردانى: مقاله حاضر مستخرج از طرحى با عنوان مطالعه

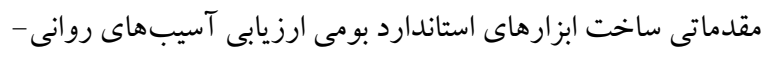

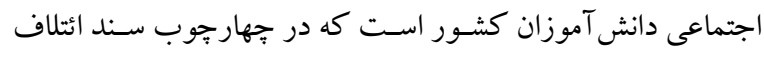
نظام مراقبت هاى اجتماعى از دانش آموزان (نماد) ذيل سند تقسيم كار

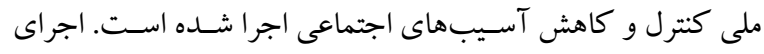

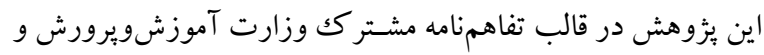

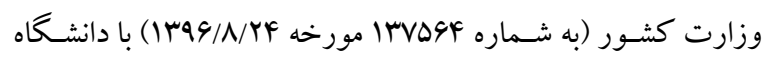

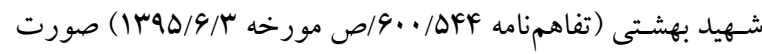

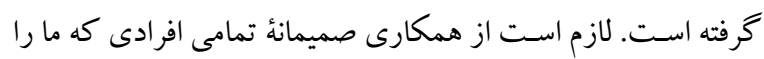
در انجام اين يزوهش يارى كردند، بهويزه معلمان، تقدير و تشـكر به آنه

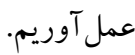
تضاد منافع: نويسـند كان مقاله در مندرجات مقاله حاضر هيج گُونه تعارض منافعى وجود ندارند.

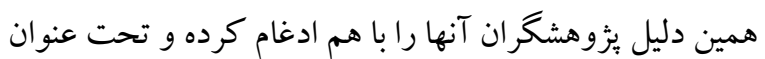
كويه آسيب رساندن و آزارديدگ همئ به آن اشاره كردند. عوامل مختلفى همانند نآ كاهى جامعه، نبود زيرساخت هاى مناسب، و و رارديل وجود محدوديت براى آموزشهاى صـحيح درباره مســائل جنسى، تمايل نداشتن دستگاههاى قضايى به افشاى بروندههاى

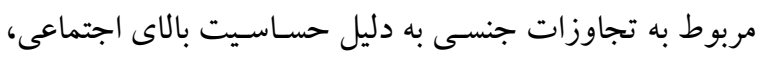
تابو بودن مسئله، وجود نو اقص و خلاءهاى قانونى بسـيارى در

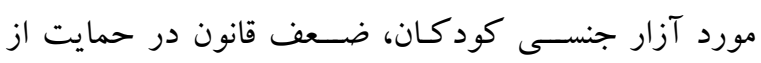
كود كان آزارديده و ترس از فرد آزاردهنده و قربانى شــدن مجدد باعث شـــ تا موارد اندكى از سـوء اسـتفاده جنسـى از

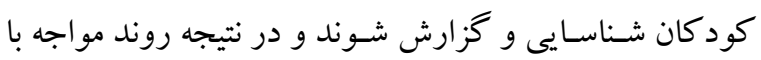
اين مشكل همجنان كند باقى بماند (Iآس).

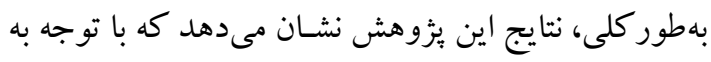

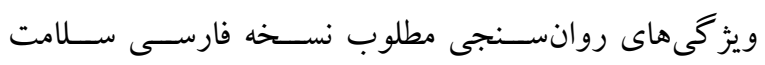

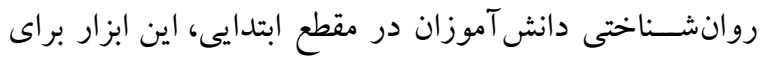

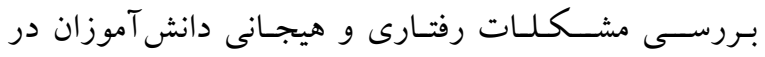
مجموعههاى آموزشىى، خدماتى و درمانى و محيطهاى بالينى

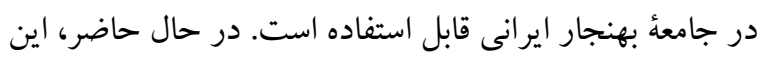
ابزار قابليت استفاده براى اندازه خيرى هفت آسيب (نارسايى در

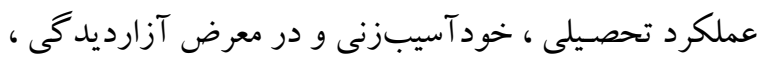

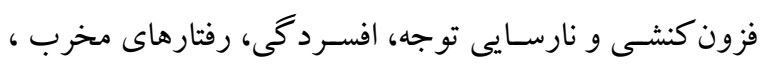

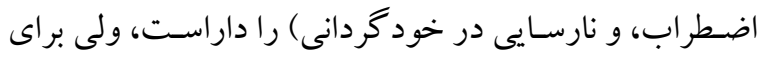
تكميل آن لازم اسـت در كنار رفع اشـكالات موجود در خردهمقياس هاى ديخر، اقدام ديخرى براى توسعه ابزار و ايجاد

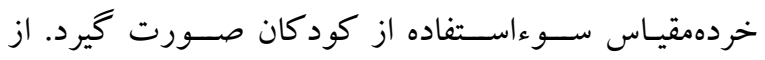
محدوديت هاى بثزوهش حاضـر مى توان به اين موضسوع اشـاره

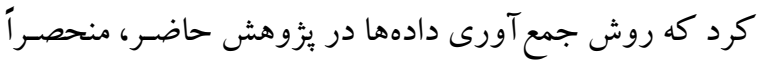

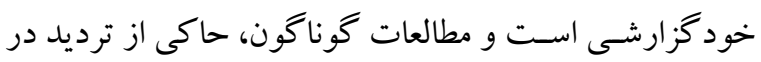

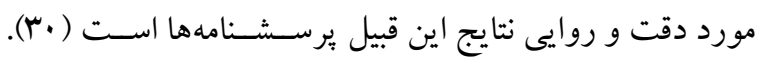

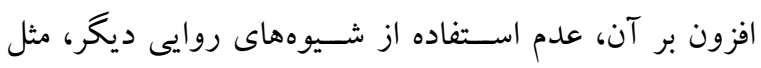




\section{References}

1. Al-Jawadi AA, Abdul-Rhman S. Prevalence of childhood and early adolescence mental disorders among children attending primary health care centers in Mosul, Iraq: a cross-sectional study. BMC Public Health. 2007; 7(1): 274. [Link]

2. Karimi M, Keikhavani S, Mohammadi MB. Efficacy of social skills training on behavioral disorders among elementary school children. Scientific Journal of Ilam University of Medical Sciences. 2010; 18(3): 6-68. [Persian]. [Link]

3. Fanti KA, Henrich CC. Trajectories of pure and co-occurring internalizing and externalizing problems from age 2 to age 12: Findings from the NICHD study of early child care. Dev Psychol. 2010; 46(5): 1159-1175. [Link]

4. Heward WL. Exceptional children: An introduction to special education. 10th Edition. Boston: Pearson; 2012; pp: 29-30. [Link]

5. Fortin L, Lessard A, Marcotte D. Comparison by gender of students with behavior problems who dropped out of school. Procedia Soc Behav Sci. 2010; 2(2): 5530-5538. [Link]

6. Ştefan CA, Miclea M. A preliminary efficiency study of a multifocused prevention program for children with deficient emotional and social competencies. Procedia Soc Behav Sci. 2010; 5: 127-139. [Link]

7. Rutter M, Kim-Cohen J, Maughan B. Continuities and discontinuities in psychopathology between childhood and adult life. J Child Psychol Psychiatry. 2006; 47(3-4): 276-295. [Link]

8. Ghobari-Bonab B, Parand A, Hossein Khanzadeh Firoozjah A, Movallali G, Nemati S. Prevalence of children with behavioral disorders in primary schools in Tehran. Journal of Exceptional Children. 2009; 9(3): 223-238. [Persian]. [Link]

9. Ghasemi O, Mousavi-Ghahfakhri A. personality assessment of childern in elementary school. Behriar Pud, Delijan. 2016; 22-34. [Persian].

10. US Department of Health and Human Services, US Department of Education, US Department of Justice. Report of the surgeon general's conference on children's mental health: a national action Agenda. Washington (DC): US Department of Health and Human Services; 2000. [Link]

11. Hester PP, Baltodano HM, Hendrickson JM, Tomelson SW, Conroy MA, Gable RA. Lessons learned from research on early intervention: What teachers can do to prevent children's behavior problems. Prev Sch Fail. 2004; 49(1): 5-10. [Link]

12. Hacker K, Arsenault L, Franco I, Shaligram D, Sidor M, Olfson M, et al. Referral and follow-up after mental health screening in commercially insured adolescents. J Adolesc Health. 2014; 55(1): 17-23. [Link]

13. Hacker KA, Penfold R, Arsenault L, Zhang F, Murphy M, Wissow L. Screening for behavioral health issues in children enrolled in massachusetts medicaid. Pediatrics. 2014; 133(1): 46-54. [Link]

14. Stifler MC, Dever BV. Mental health screening at school: instrumentation, implementation, and critical issues. 1st ed. Cham: Springer International Publishing; 2015, pp: 21-22. [Link]

15. Walker HM, Severson HH, Todis BJ, Block-Pedego AE, Williams GJ, Haring NG, et al. Systematic screening for behavior disorders (SSBD): further validation, replication, and normative data. Remedial Spec Educ. 1990; 11(2): 32-46. [Link]

16. Lane, K.L., Oakes, W.P., \& Menzies, H.M. (2014). Comprehensive, integrated, three-tiered models of prevention: Why does my school—and district — need an integrated approach to meet students' academic, behavioral, and social needs? Preventing School Failure: Alternative Education for Children and Youth, 58, 121-128. [Link].

17. Kilgus SP, Sims WA, von der Embse NP, Riley-Tillman TC. Confirmation of models for interpretation and use of the Social and Academic Behavior Risk Screener (SABRS). Sch Psychol Q. 2015; 30(3): 335-352. [Link]

18. Goodman R. The strengths and difficulties questionnaire: a research note. J Child Psychol Psychiatry. 1997; 38(5): 581-586. [Link] 
19. Goodman R, Ford T, Simmons H, Gatward R, Meltzer H. Using the strengths and difficulties questionnaire (SDQ) to screen for child psychiatric disorders in a community sample. Br J Psychiatry. 2000; 177: 534-539. [Link]

20. Lane K, Menzies H, Oakes W, Kalberg J. Systematic screenings of behavior to support instruction: From preschool to high school. 1 edition. New York: Guilford Press; 2012, pp: 10-11. [Link]

21. Sarmad Z, Bazargan A, Hejazi E. Reseach methods in behavoral science. Tehran: Agah; 2015, pp: 7779. [Persian].

22. Comrey AL, Lee HB. A first course in factor analysis. 2nd Edition. Hillsdale, NJ: Psychology Press; 1992, pp: 205-213. [Link]

23. Chronbach LJ. Coefficient alpha and the internal structre of tests. Psychometrika. 1951; 16(3): 297-334. [Link]

24. Tabachnick BG, Fidell LS. Using multivariate statistics. 5th Edition. Oston, MA: Allyn \& Bacon/Pearson Education; 2006, pp: 660-670. [Link]

25. Kaiser HF. An index of factorial simplicity. Psychometrika. 1974; 39(1): 31-36. [Link]

26. Bartett MS. Tests of significance in factor analysis. Br J Math Stat Psychol. 1950; 3(2): 77-85. [Link]

27. Kheiry H, Salehi I, Soltani Shal R. The effectiveness of stress management training on marital satisfaction and parental stress in mothers with children with behavioral problems. Journal of Child Mental Health. 2018; 4(4): 3-13. [Persian]. [Link]

28. Akbari-Zardkhaneh S, Alebuieh M, Zanganeh A, Mansurkiaie N, Jallalat-Danesh M, Mahdavi M. Parent form of psychological pathology for children: preliminary study of development and psychomentric properties. Journal of Child Mental Health. 2018; 4(4): 152-164. [Persian]. [Link]

29. Houman HA. Multivariate analysis in behavioral research. Tehran: Parsa Publication; 2001, pp: 395404. [Persian].

30. Mitchell ML, Jolley JM. Research design explained. 8 edition. Australia, Belmont, CA: Wadsworth Publishing; 2012, pp: 112-113. [Link]

31. Naghavi A, Fatehizadeh MAS, Abedi MR. A study on abused girls and the consequences of abuse on them. Women in Development \& Politics. 2004; 2(3): 125-145. [Persian]. [Link] 